\title{
The Attitude of Young People of John Paul II and Benedict XVI. Analysis of the Contents of the Speeches of the Two Popes
}

\author{
Lucio Meglio \\ Department of Human, Social and Health Science, University of Cassino and Southern Lazio, Cassino, Italy \\ Email:1.meglio@unicas.it
}

How to cite this paper: Meglio, L. (2021). The Attitude of Young People of John Paul II and Benedict XVI. Analysis of the Contents of the Speeches of the Two Popes. Sociology Mind, 11, 95-104.

https://doi.org/10.4236/sm.2021.113008

Received: June 30, 2021

Accepted: July 17, 2021

Published: July 20, 2021

Copyright $\odot 2021$ by author(s) and Scientific Research Publishing Inc. This work is licensed under the Creative Commons Attribution International License (CC BY 4.0).

http://creativecommons.org/licenses/by/4.0/

\begin{abstract}
The hypothesis of this research is that, although not explicitly stated, the attitude of the two pontiffs of youth against has been changed. A demonstration of this thesis was conducted a thorough analysis on the data provided by samples of papal speeches, using as a methodological tool program textual analysis Atlas.ti 5.0. Not only are there differences in the type of communication with young people established by the two popes, but also a different emotional tone is highlighted by the analysis of textual qualifiers. Even in some images there is a greater proximity compared to the previous public youth Pope John Paul II.
\end{abstract}

\section{Keywords}

Youth Culture, Religion, Pontiffs, Religiosity, Lifestyle

\section{Introduction}

"The Pope wants good to every man and all men, but has a preference for young people, because they had a preferential place in the heart of Christ".

This quote is from one of the many speeches that John Paul II addressed to young people represent well the close relationship between this pope and young people. The result of such passionate closeness was the institution in 1985 out of World Youth Day, an event in history, hard life of the Vatican, born with the express intent to meet, in the name of Jesus, millions of children from all over the world, the days were in fact designed by the pontiff as stopping moments where you can feed the faith through encounters with peers from other countries and the comparison of their experiences. Thus began the custom that the World Youth Day is held every year in various dioceses in the world and every two 
years with an international meeting in a place always different. Underpinning this affection and attention of the Polish pope to the younger was the firm conviction that Christianity should be "the religion of the young" although in fact the Word of the Lord to ask everyone, it reveals a special affinity with age youth for its mysterious ability to continuously relate the pace of the spiritual journey on the momentum and generosity that are typical of youth season. Interest in the younger part of Pope Wojtyla emerged clearly suffered in the first years of his pontificate. Every week in the Paul VI audience hall there was a meeting with the boys who went to the Vatican especially for this event, which over time will be institutionalized in general audience. During his apostolic journeys, and his visits to the parishes of Rome, he always dedicated a special lecture to the young (Del Rio, 2003). Of the more than 569 official speeches delivered over the years, 311 have been dedicated exclusively to children. Pope Joannes had great affection for his young people, and they had affection to him (Muolo, 2005). Initially it could have been thinking that the origin of this "attraction" was due to the natural sympathy of the character, to his office, to his way of doing, in reality over the years and with the progress of the disease, even when Pope was no longer the globetrotting once, young people have continued to follow him; a sign cha behind this connection was something deeper. Young people deeply valued John Paul, saw him as a teacher who was himself a witness and the fact pope with his life has embodied a model of credible witness: "yes" who said to Christ in his youth, he repeated until the last, even in the days of suffering. In a world in which young people no longer have benchmarks that the pope was. He has shown loyalty to his vocation, even on a wheelchair was young, without remain locked in the "Peter Pan syndrome", to the point were dying with the name of his beloved young people on the lips. With his death on April 2, 2005, John Paul II has thus left a heavy legacy to his successor: German Cardinal Joseph Ratzinger. As a character diametrically opposed to his predecessor, the new pope has been found should take mandatory steps already drawn in relation to the younger generation by Pope Wojtyla; back could not return, and the World Youth Day in Cologne they have been fatally the test.

The differences between the two popes were immediately evident. The first years of his pontificate, John Paul II devoted eighteen speeches to young people, Benedict XVI eight, less than half. Ratzinger has remained faithful to his convictions that already was able to demonstrate when he was cardinal. In an interview granted to an Italian newspaper, the then head of department for the Doctrine of the Faith said that "in the Church there is a word inflation and excessive production of documents [...] personally prefer prayers to the discussions" (Nichols, 1996).

The style of the new pope in relation to the masses of young people suffers therefore radical changes: the sobriety prevails over gaiety. Its symbolic expression is taken directly from liturgies, which are celebrated with great authority. Outside the harvest and the new catechism pontiff appears to be a minimalist. By Karol Wojtyla boys applauded the gestures and phrases effect with the new pope 
behave in the opposite way: follow the homilies delivered by Ratzinger word for word, from beginning to end. The prayer, reflection and meditation are the levers which are based on meetings with the younger generation. To the youth meeting in Cologne in August 2005, for example, once again after years of Eucharistic adoration liturgical solemnity, never presented in previous editions of pope Wojtyla.

From these premises therefore seems natural to consider a substantial change in the relationship that the two popes have towards young people. It seemed useful for those who seek a written objective empirical data to support this hypothesis. Hence the construction of the research will be presented below.

\section{Methodology and Operational Phases}

To test the hypothesis previously exposed, that the attitude towards the current pontiff younger than its predecessor has changed, it was decided to proceed to the analysis of the content of speeches that both popes have addressed the universe youth in public ceremonies. The speeches were drawn from the official site of the Holy See (https://www.vatican.va/). Obviously the number of speeches of John Paul II is far higher than those of Benedict XVI (311 Wojtyla Ratzinger-11); to remedy this disproportion was carried sampled speeches, first taking a message for each year of his papacy, 1978 to 2002, and two from 2003 to 2005, for a total of thirty speeches, compared with the eleven Benedict XVI. The textual analysis was conducted using the software Atlas.ti. The knowledge-Atlas.ti Workbench 5.0 is a software for the scientific development very powerful allowing qualitative analysis of large amounts of textual data, graphics, audio and video. This program allows, as well as the transmission of a text into an array of data, including an analysis of play content through simple processes that create key terms and quotation that travel throughout the text, linking the various documents assigned. These links can then develop a series of maps, tables or conceptual notions regarding general of selected texts. Application fields typical of this programme are characterized by a systematic method suitable and creative analysis of unstructured data (those defined "softness" that is, material that can't be properly analyzed by conventional methods, statistical and formalized). The key feature of this software scientific, is the ability to build networks that enable visually hermeneutical to link the relationship between the codes selected through diagrams. The unit hermeneutics is the main component of the programme as all data, codes, notes and the results are collected and organized it. This work was therefore based entirely on the study of exploratory and descriptive words or basic unit of analysis, understood as events "micro" able to explain "macro-history" from which it originates. The units are used for classification of type grammar. The corpus, or all data under investigation consists of 41 speeches, 30 of John Paul II, and 11 of Benedict XVI. The unit classification coincides with the grammatical elements of the text, or 6.560 words with relative frequency, 47.640 for speeches Wojtyla; 3.089 words with 14.925 frequencies for Ratzin- 
ger (Table 1).

In other has proceeded in this way:

1) Placing on two text files being blocked two speeches;

2) Application procedures for processing text of Atlas.ti files on the two above mentioned (procedures views in detail below);

3) Final considerations of output processing program.

\section{Procedure Atlas.ti}

Through Word cruncher work has proceeded to break speeches in the total frequency of the words they are made, sorted according to most often. A key step has been to exclude from the words frequently $\leq 5$, in this way we have removed 5.588 words from the speeches of John Paul II, and 2.700 from those of Benedict XVI. Next Step has been the elimination of the words with little meaning, such as conjunctions, articles, prepositions, names of persons, adverbs, pronouns, prepositions articulate, and auxiliary verb conjugations and have to be in order to determine the characteristics present all words interior of the two speeches, bringing to a total of 90 significant words (other eliminating 217) for speeches Benedict XVI, and 217 words (eliminating 794) for John Paul II (Table 2).

Last step is the operation of the "generation of equivalence". It has been assumed that in a text, there are words of different graphic form but due to the same meaning. The criterion adopted equivalence refers to plurals that is carried forward in the singular, synonyms close, and the same words with articles taken or that the program did not recognize (Table 3).

At this point terminate these operations we have the heart of the words of significant speeches of the two popes can describe and analyse. The first action that is natural is to compare the ranking of the most common words in the two speeches. In first place for Benedict XVI is God, cited 178 times, followed by Life 76, and Jesus Christ and dead heat with 69 citations. In John Paul II is the first place Young mentioned 413 times and 339 times in Christ (Table 3).

By analyzing the first two words is already quite an index indicative of the relationship between the two popes and the universe of youth. The most recurrent

Table 1. Numbers words and speeches of the popes.

\begin{tabular}{cccc}
\hline & Speeches & Number words & Frequency \\
\hline John Paul II & 30 & 6.559 & 47.640 \\
Benedict XVI & 11 & 3.088 & 14.925
\end{tabular}

Table 2. Exclusion of insignificant words.

\begin{tabular}{ccccc}
\hline & Total frequency & Frequency $\geq 5$ & Words with little meaning & Meaningful words \\
\hline John Paul II & 47.640 & 1.011 & 794 & 217 \\
Benedict XVI & 14.925 & 388 & 218 & 90 \\
\hline
\end{tabular}


Table 3. Generation of equivalence.

\begin{tabular}{cccc}
\hline & John Paul II & \multicolumn{2}{c}{ Benedict XVI } \\
\hline Word & Equivalent & Word & Equivalent \\
\hline \multirow{2}{*}{ Young } & youth & Young & youth \\
& boys & & boys \\
& student & & \\
Love & girls & Love & Of love \\
& Of love & & Men \\
Humanity & In love & Humanity & Friendship \\
Friendship & Men & Friend &
\end{tabular}

word in speeches of Pope Wojtyla is young, Ratzinger is God. The first is aimed directly at the younger generation, he calls by name, as a father does with their children, and the second, from pure Professor of Theology continually mentions the name of God. Again, the difference between the two appears significant; John Paul II in fact continually cites the Son, Christ, not the Father, making reference to the evangelical teachings of the First, much closer to understanding by the people of the faithful. When the list does not appear at first sight of the big differences in the use of certain words than others (Table 4).

In continuing the analysis is then seemed useful to construct three broad categories in which conceptual insert words attributed to the same set of meanings.

The first category considered collect words that refer to the symbolism of faith (Jesus, Gospel Church, Cross etc.). The second brings together the words that are aimed at a younger (joy, love, friends, happiness etc.). Finally the third category contains the words belonging to the ethical and moral sphere, such as family, marriage, sin, death etc. By analyzing the data showed that substantially in both speeches of the two popes the bulk of words used belongs to the category of religious symbols. Specifically the first five words of this class are almost the same for both, except for the word truth that appears to fifth place in John Paul II (Table 5).

Regarding the group of terms linked to the universe of young, basically there is no difference by the number of words used, the frequency. Specifically, it is noteworthy that Pope Ratzinger, the first even directly appoint young people refers to the word Love, and terms such as friends and joy, both linked to the sphere of personal feelings. The word love, in particular hour alternately refers to feeling that binds "naturally" a man and a woman and that is in the process of completing the family hour to Love the Lord directed towards men, are a significant step taken from one of his speeches: Redeemed his blood, no human life is unnecessary or of little value, because we are all loved by him personally with a passionate and faithful love, a love without limit.

The confirmation of this pontiff addressed this form "pure" sentiment, we 
Table 4. First ten words with total frequency.

\begin{tabular}{cccc}
\hline & John Paul II & \multicolumn{2}{c}{ Benedict XVI } \\
\hline Word & Frequency & Word & Frequency \\
\hline Young & 413 & God & 178 \\
Christ & 339 & Life & 76 \\
God & 264 & Christ & 69 \\
Jesus & 191 & Jesus & 69 \\
Humanity & 172 & World & 55 \\
World & 169 & Love & 55 \\
Love & 151 & Heart & 54 \\
Church & 142 & Humanity & 50 \\
True & 121 & Young & 46 \\
Faith & 94 & Friend & 46 \\
\hline
\end{tabular}

Table 5. Religious symbols. First twelve words.

\begin{tabular}{cccc}
\hline & John Paul II & \multicolumn{2}{c}{ Benedict XVI } \\
\hline Word & Frequency & Word & Frequency \\
\hline Christ & 339 & God & 178 \\
God & 264 & Christ & 69 \\
Jesus & 191 & Jesus & 69 \\
Church & 142 & Church & 41 \\
True & 121 & Lord & 40 \\
Faith & 94 & Faith & 26 \\
Lord & 93 & Writing & 19 \\
Gospel & 81 & Communion & 14 \\
Spirit & 52 & Spirit & 13 \\
Mission & 48 & Cross & 10 \\
Cross & 46 & Gospel & 10 \\
Prayer & 45 & Prayer & 8 \\
\hline
\end{tabular}

find in his first encyclical published at the end of 2006 to eloquent title: "Deus Caritas Est", dedicated to the analysis of how to form high love of God to men. For Benedict XVI faith must be lived as concrete experience that involves "the heart, intelligence and freedom"; Christianity will be understood as "a great will to love and to life. It is therefore a pope who wants to explain to the younger generation more intimate size and depth of religion".

Even John Paul II, the word love appears frequently, but here it is used more to encourage young people to direct their actions towards love towards God and neighbor: "May the love and service are the basic rules of your life". In the first once there is the teaching of "professor" that explains and interprets the feelings 
in a purely theological, in the second perceive the warnings of "shepherd" who shows the way that their flock must follow.

The third group of words taken from the significant speeches of the two pontiffs, collects the terms due to ethical and moral sphere.

The word that occurs more in both man is "the Church can't abandon man" with this sentence Pope John Paul II opened one of its first social encyclicals, demonstrating that the focus of the Magisterium of the Catholic Church is totally focused on the care and preservation of man: "Man is the primary route that the Church must travel in fulfilling her mission: he is the primary and fundamental way for the Church". Human life for both pontiffs must never be regarded as a second, the first commitment of the Church is to defend the absolute primacy of the human person (Table 6).

When the list, however, note in both speeches that there are different words for each other and for the pontiff. In John Paul II is the presence of terms like company, person, dignity, and even down progress, science, social justice etc.; Terms used frequently by this pontiff also outside these speeches. The Woytjla attention to issues of social justice work and is witnessed by drawing many of its social encyclicals that have enriched if not transformed in part, the social doctrine of the Catholic church, his writings have not only accepted and confirmed acquisitions latest "social discourse" of the Church, but they have also developed a new message that continuity with the teaching front, opening new horizons of the third Christian millennium: "The Church's social doctrine contains the principles of a response that respects the role of individuals and groups". In Ratzinger not ever find any quote that invests these fields, he put the emphasis on traditional morality issues such as Catholic support for the family "natural": The love of man and woman is at the origin of human family and the couple formed by a man and a woman has its foundation in the original plan of God. A little curiosity is found in the lack Ratzinger of the word "sin" in this rather Wojtyla, a disappointment for those assigned to this role of the pontiff great Inquisitor.

In summary in both speeches most of the time belongs to the group of religious symbology (539 for Benedict, 2017 for John Paul), followed by those who fall within the terms of group dedicated to the younger (265 Benedict, 957 John Paul), and finally the group belonging to the ethical and religious sphere (137 against 755) (Table 7).

The full-bodied presence in terms of papal speeches due to the religious symbolism, is not a surprising. In frequency has indeed proceeded to have a further confirmation of these data using another source which the database of Italian spoken. Available on the Internet at:

http://languageserver.uni-graz.at/badip/badip/home.php. Badip is a free site dedicated to the publication of corpora for the analysis and study of Italian spoken that Language is part of the server Karl Franzens University Graz (Austria). Inside the site contains an on-line version of Corpora most important vocabulary frequency of Italian spoken published by 1965 onwards. This corpus is the 
Table 6. Words referring to the youth universe.

\begin{tabular}{cccc}
\hline & John Paul II & \multicolumn{2}{c}{ Benedict XVI } \\
\hline Word & Frequency & Word & Frequency \\
\hline Young & 446 & Love & 55 \\
Love & 151 & Hearth & 50 \\
Hearth & 92 & Friends & 46 \\
Joy & 53 & Young & 46 \\
Friends & 53 & Joy & 26 \\
Loyalty & 22 & Happiness & 10 \\
Happiness & 18 & Companionship & 9 \\
Beauty & 14 & Confidence & 9 \\
Confidence & 14 & Affection & 7 \\
Fraternity & 12 & Beauty & 7 \\
Feeling & 10 & & \\
Serenity & 7 & & \\
\hline & & & \\
\hline
\end{tabular}

Table 7. Words referring to the moral-ethical sphere.

\begin{tabular}{cccc}
\hline & John Paul II & \multicolumn{2}{c}{ Benedict XVI } \\
\hline Humanity & 172 & Humanity & 54 \\
Hope & 56 & Family & 14 \\
Peace & 53 & Nature & 13 \\
Society & 47 & Death & 10 \\
Person & 39 & Woman & 9 \\
Freedom & 31 & Future & 8 \\
Family & 25 & Marriage & 8 \\
Salvation & 25 & Justice & 7 \\
Death & 24 & Freedom & 7 \\
Sons & 20 & Peace & 7 \\
Dignity & 19 & & \\
Justice & 19 & & \\
\hline
\end{tabular}

collection of texts used in the most important linguistic research; its 469 texts, containing a total of approx. 490.000 words, were collected in four cities (Milan, Rome, Florence and Naples), and from five macro classes and several subclasses of speech. By inserting the words collected in our research, and restricting the analysis only to terms that fall within the context object of this study, it was found that the most frequent citations within religious messages are "God" and "Christ" confirming that the bulk of the terms used by popes concerns for precisely the religious symbolism. 


\section{Conclusion}

At the opening of this article, presenting this research, has proposed the hypothesis that the attitude of the pontiff against the world of the young has been changed compared to its predecessor. To demonstrate this argument has proceeded to play a series of data from text of speeches that both popes have spoken at their meetings with young people. Before you can say if the idea has been "scientifically" proven or not, I think we should make some clarification on the methodology of analysis used.

In the history of social research, analysis of the content has never enjoyed high esteem within the scientific community. The causes of this lack of confidence can be attributed to Corsican proliferate in the years of research that have resorted to analysis techniques rather naive, who have in some way undermined the credibility of the text. One of the most frequent criticisms directed to studies of the content analysis is to produce results without rigorous logic, along with a mass of documents unreadable and difficult to analyze. In fact, in recent years the use of scientific software in this research has offered a valid response to this type of criticism. If a high stringency of the procedures is guaranteed by the possibility of any explicit path analysis assisted by a computer, the wide use of texts becomes an advantage rather than a disadvantage. The tool therefore becomes a valuable tool to guide the researcher in analysis, but it can't replace it in any way, as rightly Rositi (1970) points out, the media are responsible for "helping the judgement does not replace it". We must always bear in mind that the results of research analysis of textual content are eminently exploratory and descriptive.

The limit of this work we have in mind concerns undoubtedly the disproportion between the number of speeches of John Paul II and Benedict XVI. Bolasco (1999) defines a small body when not exceeding 15.000 occurrences, when it reaches the average 45.000 hits and finally medium-sized when exceeding 100.000 .

In our case it has had to do with a small corpus for speeches by Ratzinger (14.925 hits), and average per speeches Wojtyla (47.640). Therefore, it could be argued that the texts of Benedict XVI are not significant to represent her in the attitude towards young people. Here I do not want to say with some certainty that he fully understood the attitude of the Pope towards young people. One has in mind how complex and the study of the attitudes and opinions. He simply tried to build a given on which to build a series of reflections. The reading of the data presented above, has shown that some fund differences in the two pontiffs with the youngest in fact exist, and you can find as to call them, in language and in the strength of the messages.

Differences can also identify the gestures and in the construction stage of events. By analyzing images from World Youth Days, (for John Paul II we looked at the 2000 Rome to view the extraordinary participation of young people), immediately jump in the eyes of the basic fundamental differences. In Rome, the Polish pope was seated among young people, among them. The vigil 
over at the time of spiritual reflection, housed inside moments of music, dance, activities of the boys, and the pontiff participated actively in these rituals, for example, following the rhythm of songs with movements of arms, without embarrassment or embracing any kids that is approached seeking blessings and caresses, breaking every rule ceremonial. In Cologne in 2005 instead at the first day presided over by Pope Ratzinger, the scene was quite different. A strike now was the location of the stage, which was built on top of a hill, which were thousands of young people during waking and the municipality. The pontiff was high compared to the crowd, the human contact was minimal and that the content of the ceremonies has not provided moments of "entertainment" has been introduced such as Eucharistic adoration. Another visual aspect to be underlined is the clothing used by the two popes. Wojtyla has always preferred the traditional dress by Pope (white tunic), Ratzinger always uses public occasions in the vestment's officers.

These differences are certainly an expression of deep character differences between the two popes, the first Wojtyla extrovert, full of vitality and always ready to improvisation, the second reflective, and more meditative. In a word, the Polish pope can be defined as between a shepherd his flock, the pope as a German theologian among its students. Let us not forget that Wojtyla had in the past from a youth actor and sports, while the life of Ratzinger was center study and contemplative life. The first prisoner of German troops, the second soldier the same. Two people completely different in character and in the lives yet accumulated by the same fate: popes of the Roman Catholic Church. Differences in attitudes are and we are evident, but this certainly does not undermine the affection and popularity that the current pontiff is gaining among the ranks of Pope "wojtyliani" boys.

\section{Conflicts of Interest}

The author declares no conflicts of interest regarding the publication of this paper.

\section{References}

Bolasco, S. (1999). Analisi multi-dimensionale dei dati. Carocci.

Del Rio, D. (2003). Karol, il grande. Storia di Giovanni Paolo II, Paoline ed.

Muolo, M. (2005). Generazione Giovanni Paolo II. Ancora.

Nichols, A. (1996). Joseph Ratzinger. S. Paul ed.

Rositi, F. (1970). L'Analisi del contenuto come interpretazione. Eri. 